\title{
Build it and they will come: grasshoppers check-in to a grassland bee hotel
}

\author{
TIM GARDINER', KIMBERLEY FARGEAUD ${ }^{2}$
}

1 Environment Agency, Iceni House, Cobham Road, Ipswich, Suffolk, IP3 9JD, UK.

2 École Pratique des Hautes Études, Les Patios Saint-Jacques, 4-14 Rue Ferrus, 75014 Paris, France.

Corresponding author: Tim Gardiner (tim.gardiner@environment-agency.gov.uk)

Academic editor: Alina Avanesyan | Received 22 July 2018 | Accepted 30 August 2018 | Published 3 October 2018

http://zoobank.org/ECDA0256-4265-4ABC-B7F2-48B64BE12E3D

Citation: Gardiner T, Fargeaud K (2018) Build it and they will come: grasshoppers check-in to a grassland bee hotel. Journal of Orthoptera Research 27(2): 159-161. https://doi.org/10.3897/jor.27.28385

\begin{abstract}
A five-floor bee hotel was constructed using wooden pallets in an area of urban grassland in Ipswich, United Kingdom. Within one month of construction, two grasshopper species were observed using the hotel, with nymphs in shaded, uncut grass at the base, while adults were observed on all five floors and the roof. On the fourth floor, a stridulating field grasshopper, Chorthippus brunneus, was sighted on two separate occasions. Further research is required to determine whether bee hotels may be an effective 'shade' refuge for grasshoppers in open grassland, while also providing an effective platform for stridulation.
\end{abstract}

\section{Key words}

Acrididae, biodiversity, bug hotel, conservation, urban

\section{Introduction}

In urban areas, bee hotels are considered to be part of the solution for reversing pollinator declines linked to loss of foraging and nesting habitats (Moenen 2012, MacIvor and Packer 2015). Many bee hotels specifically focus on providing cavities for a range of above-ground bee species to nest in (Gaston et al. 2005). To provide these nest sites, various materials are used including bundles of dry stems and holes drilled in wood (Lee-Mäder et al. 2010, Vickruck and Richards 2012). However, concern has been expressed about the efficacy of these hotels in conserving the intended bee species due to parasitism of nests (MacIvor and Packer 2015). The apparent use of bee hotels by other taxa is also not well reported in the scientific literature. It is with this latter point in mind that the usage of a bee hotel by grasshoppers (Orthoptera: Acrididae) was studied in an urban grassland in the UK. The findings are discussed in relation to the biology of the grasshopper species observed and further research is suggested.

\section{Methods}

Bee hotel construction. - A bee hotel was constructed from wooden pallets (Fig. 1) in a well-drained grassland area at the Environment Agency's Ipswich office in Suffolk, United Kingdom (Ordnance Survey grid reference: TM 19277 42710).
The bee hotel was constructed on 21 June 2018 using five wooden pallets (each $80 \times 120 \mathrm{~cm}, 13 \mathrm{~cm}$ height) placed on top of each other to create a five-floor structure. Within the gaps in the pallets, oak (Quercus robur) branches and cut reeds (Phragmites australis) were placed in bundles. The bottom story was left unfilled to allow vegetation to grow through the hotel creating a more natural habitat for insects. The hotel was in full sun for most of the day, with shade provided by overhanging vegetation (bramble, Rubus fruticosus) on a first-floor 'gallery' created by the base pallet being larger than those above. On the roof of the fifth-floor pallet, plastic plant pots of shingle were placed to create nesting sites for bees along with dried shrub leaves to provide cover from rain. Holes were drilled in the wooden pallets to create nesting sites for solitary bees.

Grasshopper and microclimate surveys.-The bee hotel was inspected on seven occasions (for around 15 mins each time) from 12 July to 1 August 2018 with a thorough inspection of basal vegetation, all floors (and roof) and the vegetation on the 'gallery'. To determine whether the frequency of grasshopper observations was significantly different than expected, a one-way Chi-square $\left(\chi^{2}\right)$ goodness of fit test was undertaken.

On 30 July ( $1600 \mathrm{~h})$ a thermometer was used to record the ambient air and compare it with microclimatic temperatures of the five floors and roof of the bee hotel. The ambient air temperature at $1 \mathrm{~m}$ from the ground was compared to the temperature of the five floors and roof of the bee hotel. To compare the microclimate of the main fill materials, the mean temperature of the reed (floors two and four) and oak branch (floors three and five) bundles was compared using a Student's t-test.

\section{Results and discussion}

On 12 July $(1600 \mathrm{~h})$, less than one month after construction, a field grasshopper, Chorthippus brunneus, late instar nymph was seen in shade on the second floor and a lesser marsh grasshopper, Chorthippus albomarginatus, was observed singing from grass at the base of the first-floor pallet. A male C. brunneus was also seen stridulating from the fourth floor. A further stridulating male of this species was sighted singing from a reed bundle on the fourth floor on 1 August. 
On 13 July (1630 h), a further three grasshoppers were sighted on the hotel. Two adult male C. brunneus were seen in grass at the base of the first-floor pallet, while a nymph of the same species jumped from an adjacent bramble leaf onto the second floor. The mean microclimatic temperature for the five floors and roof $\left(25^{\circ} \mathrm{C}\right)$ was lower than the ambient air temperature at $1 \mathrm{~m}$ above ground $\left(27^{\circ} \mathrm{C}\right)$. Therefore, grasshoppers may be using the bee hotel as a source of shade from excessively hot microclimatic temperatures in the sparse grassland in an unusually hot and dry spell similar to the summer of 2003 (Gardiner and Hassall 2009). This kind of behavioral thermoregulation to avoid overheating is well known in Orthoptera (Willott 1997).

Furthermore, mean temperature difference (from ambient air temperature) in the reed bundles of floors two and four $\left(-2.5^{\circ} \mathrm{C}\right)$ was significantly different $(\mathrm{t}=3.68, \mathrm{P}=0.03)$ from that of the oak branch bundles of floors three and five $\left(-1.3^{\circ} \mathrm{C}\right)$. This suggests that the fill material for the pallet layers could have a key influence over the usage of the bee hotel by insects as a shade refuge from high temperatures, with bundles of reed being particularly cool. Unfortunately, there were not enough observations in this small study to statistically test the issue, although only two grasshoppers were sighted on the warmer oak bundles compared to seven on the cooler reed (Fig. 2). We suggest further detailed experimental design with replication to test the efficacy of bee hotels in providing habitat for grasshoppers in grassland. These studies should allow meaningful statistical analysis to be undertaken.

The observation of grasshoppers stridulating from the fourth floor suggests that the hotel may also form an effective platform from which to broadcast mating calls, perhaps providing an advantage over enclosed vegetation (Robinson and Hall 2002). It is unlikely that grasshoppers will use the hotel for feeding due to the dry nature of the reed in the bundles and presence of woody vegetation (Gardiner and Hill 2004). However, shaded grass at the base of the hotel may provide a suitable feeding environment of 'live' vegetation away from the high temperatures of the open grassland. The grassy vegetation growing through the 'gallery' may also be a suitable feeding environment for grasshoppers. However, the distribution of grasshoppers on the hotel was not significantly different from that expected (Chi-square $\chi^{2}=10.5$, d.f. 5, P $=0.06$ ) with the lower two floors (including the 'gallery') having the most observations (Fig. 3).

Additional observations were undertaken in August 2018 on a grassland bee hotel in Dedham, UK (approx. $16 \mathrm{~km}$ south-west of Ipswich bee hotel). A meadow grasshopper, Chorthippus parallelus, and long-winged conehead, Conocephalus fuscus (Orthoptera: Tettigoniidae), were observed in basal vegetation while the former species was also sighted on the roof. These observations would seem to concur with those from Ipswich that bee hotels and their immediate grassland surroundings have some value for Orthoptera.

In conclusion, further experimental research is required to determine whether bee hotels may be an effective 'shade' refuge in open grassland with little cover, while also providing an effective platform for stridulation. Replicated studies from a wide range of bee hotels would further aid the design to promote use by nontarget insects such as grasshoppers.

\section{Acknowledgements}

We would like to thank Buglife and David Dowding for providing inspiration for the creation of the bee hotel and to Mark Shefford of the Environment Agency for help with its siting and establishment.

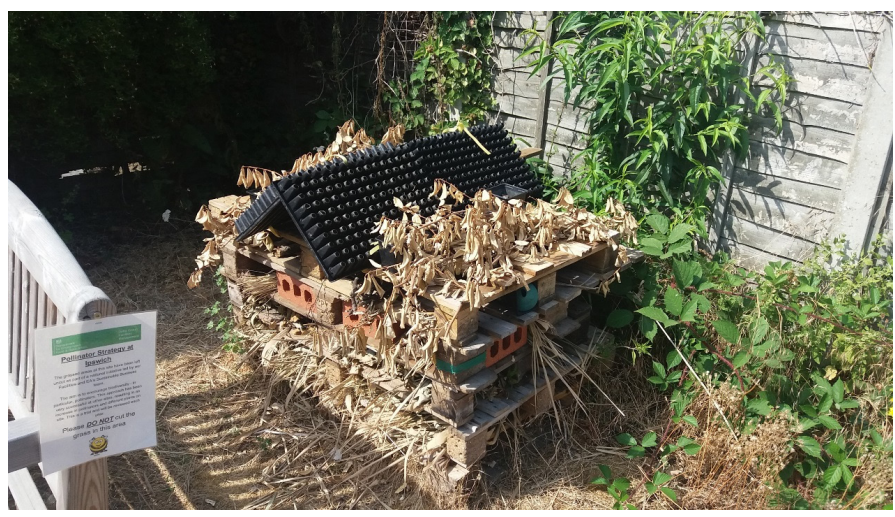

Fig. 1. The bee hotel. Photo credit: T. Gardiner.

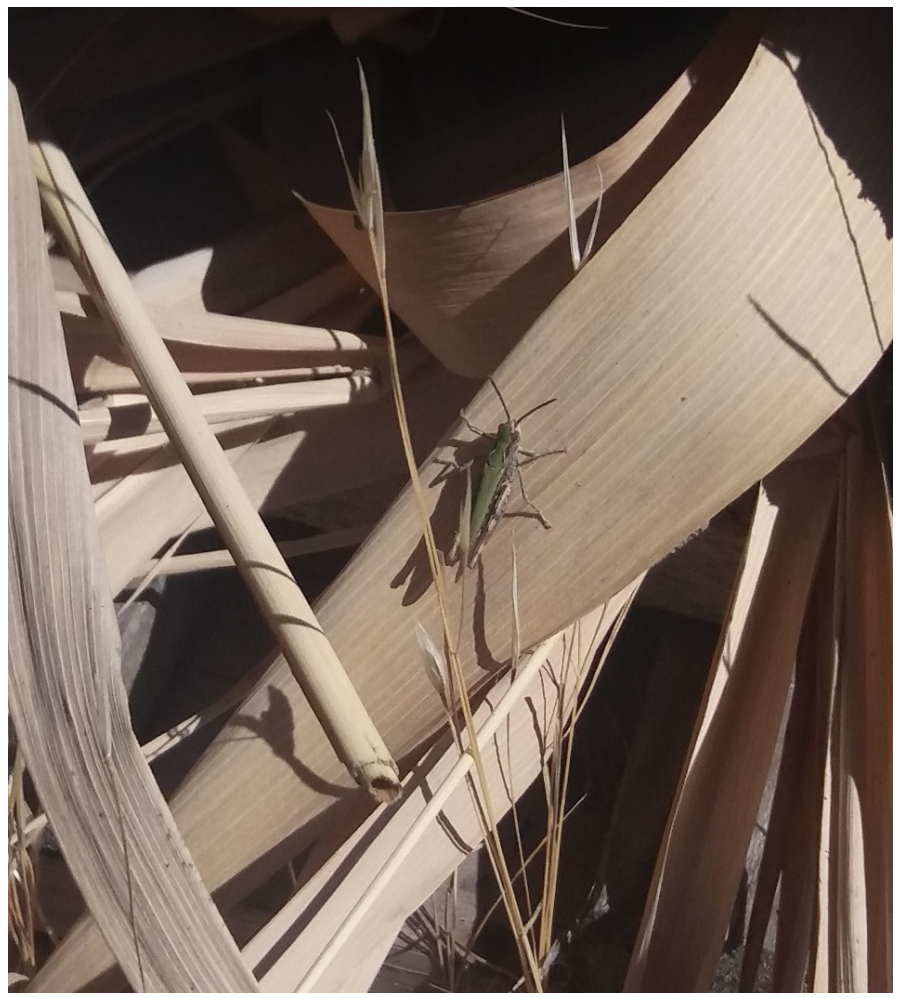

Fig. 2. Male field grasshopper, Chorthippus brunneus, on fourthfloor reed bundle, observed stridulating. Photo credit: T. Gardiner.

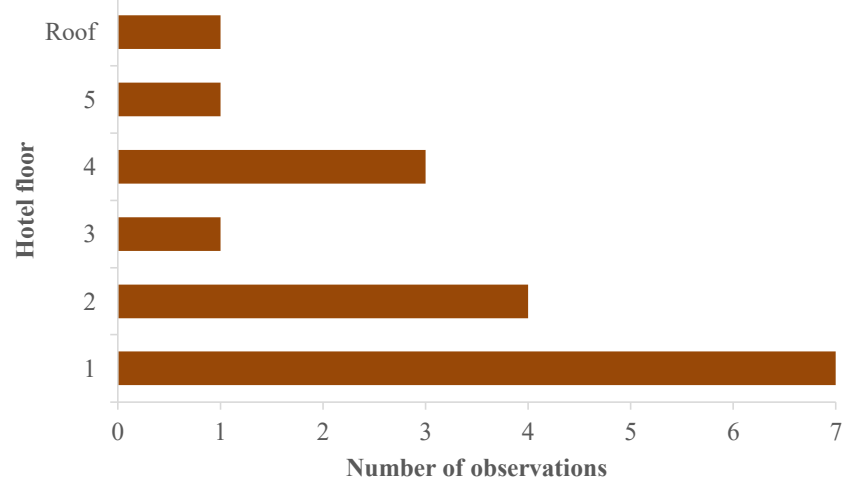

Fig. 3. Frequency of observed grasshoppers on the five floors and roof of the bee hotel. 


\section{References}

Gardiner T, Hassall M (2009) Does microclimate affect grasshopper populations after cutting of hay in improved grassland? Journal of Insect Conservation 13: 97-102. https://doi.org/10.1007/s10841007-9129-y

Gardiner T, Hill J (2004) Feeding preferences of Chorthippus parallelus (Orthoptera: Acrididae). Journal of Orthoptera Research 13: 197203. https://doi.org/10.1665/1082-6467(2004)013[0197:FPOCPO] 2.0.CO;2

Gaston KJ, Smith RM, Thompson K, Warren PH (2005) Urban domestic gardens (II): Experimental tests of methods for increasing biodiversity. Biodiversity and Conservation 14: 395-413. https://doi. org/10.1007/s10531-004-6066-x

Lee-Mäder E, Spivak M, Evans E (2010) Managing alternative pollinators: A handbook for beekeepers, growers, and conservationists. Sustainable Agriculture Research and Education, New York, 186 pp.
MacIvor JS, Packer L (2015) 'Bee Hotels' as tools for native pollinator conservation: a premature verdict? PLoS ONE 10: e0122126. https://doi. org/10.1371/journal.pone.0122126

Moenen R (2012) De broedparasiet Cacoxenus indagator (Drosophilidae) en de parasitoïden Melittobia acasta (Eulophidae) en Coelopencyrtus sp. (Encyrtidae) bij solitaire bijen in kunstmatige nestgelegenheid. Entomologische Berichten 1-2: 63-70. https://www.nev.nl/pages/ publicaties/eb/nummers/2012/72-1-2/63-70.pdf

Robinson DJ, Hall MJ (2002) Sound signalling in Orthoptera. In: Evans P (Ed.) Advances in Insect Physiology 29. Elsevier, 151-278.

Vickruck JL, Richards MH (2012) Niche partitioning based on nest site selection in the small carpenter bees Ceratina mikmaqi and C. calcarata. Animal Behaviour 83: 1083-1089. https://doi.org/10.1016/j. anbehav.2012.01.039

Willott SJ (1997) Thermoregulation in four species of British grasshoppers (Orthoptera: Acrididae). Functional Ecology 11: 705-713. https://doi. org/10.1046/j.1365-2435.1997.00135.x 